\title{
The USA's (Non-) Basing Strategy in the 2000s: A reappraisal
}

\author{
Alyson JK Bailes, Adjunct Professor, University of Iceland.
}

\begin{abstract}
After the terrorist strikes of 2001 the US adopted an interventionist military posture that saw overseas bases as transit and access points for combat zones, rather than as tokens and instruments of long-term cooperation with Allies. US stationed forces in Europe were thinned out further while new missile defence bases were planned close to Russia's frontiers. Major basing changes were also planned in the Far East, tending to reduce the direct territorial support for local partners. These shifts caused turbulence abroad at the time and were also challenged by Congress on cost grounds. In retrospect, the military-technical concept behind them can be criticized as relying excessively on rapid intervention and remote strikes, while underplaying ground control and the importance of local expertise. Politically the new approach overlooked both the importance of established partnerships in democratic regions, and the multi-sided symbolism of bases themselves. In strategic terms, the post-9/11 military doctrine now looks over-risky, one-sided and inadequate to serve the full range of vital US interests in a globalizing, interdependent world. President Obama's new strategic goals recognize this, but are unlikely to lead to restoration of old-style bases on any significant scale. Yet the importance of controlling territory and being able to exploit its resources looks set to grow, rather than decline further, in view of the climatic, economic and demographic trends of the present century.
\end{abstract}

\section{Introduction}

When the USA announced in March 2006 its unilateral troop withdrawal from Iceland, this decision marked the end to a specific tug-of-war with the Icelandic authorities that went back at least to 1991. However, it also fitted into a larger pattern of US military base closures and troop reductions in Europe that began even during the Cold War, was boosted by the Cold War's end and was further accelerated under the Administration of George W. Bush. Bases elsewhere (e.g. in East Asia) were retained but relocated as part of the same trend, and smaller new ones were installed or planned where none had been before, including in strategically sensitive parts of East-Central Europe and Central Asia. Not only in Iceland but in every region affected by these changes, serious 


\section{STJÓRNSÝSLA}

protests and warnings about the consequences were heard from the USA's allies, or from unfriendly powers, or both. Yet the programme was pushed through right up to the Republican Party's defeat in the 2009 Presidential elections, and in some cases even beyond. By 2010, nearly half of all bases used in the Cold War had been shut, and the great majority of US soldiers serving abroad were not in fixed garrisons but on ad hoc combat missions such as that in Afghanistan.

What did US strategists and politicians hope to gain by carrying through such a revolution in the country's worldwide military posture, and what motives were strong enough to make them sweep such widespread protests aside? This short study will not only try to answer these questions, but also to take a fresh critical look at the answers, five years after the US withdrawal from Keflavik. The features and aims of the base closure programme beyond Iceland will be outlined in section 2, and in section 3 its logic will be questioned from three angles: military-technical and operational aspects, political aspects, and strategic logic based on threat analysis. A speculative conclusion discusses how the importance of controlling foreign territory may or may not change further during the $21^{\text {st }}$ century.

\section{US Military Basing Strategy, 1990-2010}

After World War Two the USA was more clearly than ever a global power, with new motive to spread its military presence world-wide to combat the equally global challenge of Communism. As shown in Table 1 below, it was not only in Europe that an unprecedentedly large US troop presence was retained after the war's end, providing the most concrete symbol of Western collective defence within the new framework of NATO. The USA also had legally binding obligations for the defence of Japan and (following the Korean war) South Korea, plus multilateral commitments in the Middle East (Central Treaty Organization, CENTO), South-East Asia (SEATO), and Australasia (ANZUS). While CENTO and SEATO collapsed relatively soon and New Zealand put limits on ANZUS cooperation, the USA did retain commitments in the Asia-Pacific region that called for a substantial troop presence nearby in case of a need for intervention. Thus even at the end of the Cold War in 1990, there were as many as 50000 US personnel in Japan, 43 000 in South Korea, and 17000 in the Philippines, in addition to the 309000 in European NATO countries (including some 3000 in Iceland). ${ }^{1}$ Equally significant, at that moment there were no US troop deployments of note anywhere else around the globe - although the USA did contribute smaller numbers to a number of UN peace missions.

\section{Figure: US Force Personnel Stationed Overseas, in thousands}

\section{Europe}

Of which: Germany Italy Iceland

1990
240

72
15

12
Japan S Korea

Iraq Afghanistan
43

35
29

150 
When the Cold War ended in 1989-90, one of its most dramatic effects was to dissolve the Warsaw Treaty Organization ('Warsaw Pact'), signal the end of Soviet military basing on former allies' territory in Central Europe, and - a few years later - remove all Russian forces from the Baltic States. The new, smaller, Russian Federation also gradually gave up its overseas bases in order to focus on the security of its homeland and its relations with new ex-Soviet neighbours. All this radically changed the rationale for US basing in Europe, even if NATO itself survived and was soon to take on new roles in the Western Balkan conflicts. From the early 1990s, while other Western states were slashing their overall force sizes and budgets to celebrate the 'peace dividend', the USA developed a programme of base closure and troop repatriation that particularly cut back on the thickest zone of Cold War deployment in Western Germany. ${ }^{2}$ Around 60\% of US bases abroad were affected and as many as 97 had been closed already by 1995, while more than 270000 army and air force personnel were brought home. Bilateral basing programmes with some countries like Spain and the Philippines were ended completely at their request. However, the total number of foreign bases and installations (of all sizes) remained high at 766, compared with 2965 on the USA's own territory. The pattern of permanent basing was moreover still close to that of Cold War times, with a dominating majority of personnel in Europe, followed by Japan and South Korea.

The first Presidency of George W. Bush brought a new, perhaps equally profound strategic shift, which it is natural to link with the massive terrorist attacks that the USA suffered on 11 September 2001. That event indeed reoriented the whole US strategic agenda almost overnight from its focus on old state enemies to new, non-state and transnational ones like terrorism - with the failed or 'rogue' states that abetted it - and from Europe and the Northern hemisphere in general to the 'Arc of Crisis' stretching from the Mediterranean to Central and South Asia. This new vision and its consequences were spelled out very plainly in the Bush Administration's first National Security Strategy published in September 2002. ${ }^{3}$ Notably and controversially, the Administration gave such high priority to the USA's own 'homeland security' that it came to view multilateral security ties, institutions, and even the constraints of international law as instrumental in the best case, and as obstacles to be disregarded in the worst.

Powerful as it was, however, this strand in US motivation was not the only one affecting basing policy under President Bush. Already before winning the 2000 elections, he and his team had promised a major overhaul and updating of US military structures that would cut costs and boost efficiency by eliminating outdated programmes, and creating forces better adapted for new-style crisis management missions. A Quadrennial Defense Review carried out during 2001 concluded that $20-25 \%$ of existing overseas bases were unnecessary ${ }^{4}$ and already in August of that year, Secretary of Defense Donald Rumsfeld authorized an Efficient Facilities Initiative ${ }^{5}$ that would produce concrete closure plans by 2003 .

The result of these converging pressures was seen on 16 August 2004 when the President announced plans to bring a further 60-70 000 US troops back from foreign bases to the homeland by 2014, retaining just 550 foreign bases. By that time, of course, major 


\section{STJÓRNSÝSLA}

US deployments had also been made to new theatres of conflict - Afghanistan and then Iraq - on a scale not witnessed since the Vietnam war. What was happening was, in other words, not so much an overall cutback in the use of US military force overseas as a massive realignment of its nature and aims. The new targets of the 'Global War', namely terrorism, WMD proliferation and associated state enemies, were accompanied by a new militarytechnical doctrine that rejected the notion of being 'pinned down' in specific strategic locations, calling instead for smaller, mobile, integrated force units armed with precision strike weapons that could be deployed in days literally world-wide. As explained in the Pentagon's 'Integrated Global Presence and Basing Strategy' (IGBPS) of 2004, , this concept would be served by a limited number of main operating bases (MOBs); smaller 'lily pads' through which forces could stage to conflict zones; and a variety of specialized sites - with few or no US personnel - for prepositioning of equipment, supply services, infrastructure facilities and the like. By definition, all bases other than MOBs would be flexible and subject to re-siting and/or role change, always moving as close as possible to ongoing theatres of operation. Large static investments would be avoided inter alia by sharing them where possible with reliable local allies, an example being the joint use of Hungary's (former Soviet) air bases of Taszár and Pápa during the Balkan wars.

It is fair to say that this new concept caused turbulence everywhere that it was applied, not least in Iceland: but the impact was complex and varied from one region to another. In Europe, further cuts were to some extent balanced by the designation of several existing bases as MOBs, although their pattern shifted distinctly southwards (note that in Table 1, the figures given for Italy in 2006/7 have decreased much less than in Germany). NATO as a whole was also prepared to go along with US thinking to some degree by streamlining its own collective base structure ${ }^{7}$ and, in August 2003, by taking over joint responsibility for the Afghanistan operation. ${ }^{8}$ What caused much greater trouble were the US plans to set up 'lily pad'-type bases in Bulgaria and Poland and then - as announced in 2007 - to install missile defence bases in Poland and the Czech Republic, as part of yet another strategic programme aiming to protect the homeland. Russia, which still saw bases as symbols of influence and vehicles of geo-political as well as military dominance, ${ }^{9}$ objected violently to the latter plans; but they were problematic also in terms of NATO politics since they reflected purely bilateral agreements that could lead to some Allies being better protected by the USA than others. ${ }^{10}$ Further friction arose with Russia over new temporary base facilities that the USA, and also Germany, acquired in Central Asian countries to support the Afghanistan operation. In 2005 a Summit meeting of the Shanghai Cooperation Organization, made up of Russia, China and four Central Asian states, called for the earliest possible withdrawal of all such Western intrusions, and Uzbekistan indeed threw US forces out though Kyrgyzstan accepted a higher rent to allow them to stay. ${ }^{11} \mathrm{~A}$ final controversial and divisive issue was the alleged use of US and shared bases in Eurasia for secret transfer flights carrying terrorist suspects, sometimes including stopovers where they were subjected to torture. ${ }^{12}$

In the Far East, planned changes in US basing had if anything larger strategic implications than in Europe, given the scale of the possible threat from China and the relative weakness of the local states' forces, with no overall regional alliance. At the 
same time, in Japan especially, there was considerable opposition to the bases at grassroots level, fuelled by incidents involving US personnel. The USA was willing to close or reduce some of the more contentious sites, but it proved hard to find new ones where the public would welcome US troops, and the negotiations to solve this (with the related cost-sharing arrangements) dragged on to as late as $2010 . .^{13}$

Conversely, the Pentagon's plans to pull back some forces to the US island of Guam, or all the way to the homeland, sparked doubts among defence-minded Japanese and Koreans that Washington might be planning more flexible responses to any war in the area - no longer having so many 'human shields' in the front line of a Chinese attack. Analysts have seen this set of issues as one of several factors that have made US-Japanese relations more complex and volatile in recent years, leading to unusually open debates about whether Tokyo should develop a more robust defence of its own, or should 'reinsure' by seeking a more stable relationship with China. ${ }^{14}$ These are uncertainties that the region can ill afford, at a time when China's own military expansion plans and North Korean nuclear adventurism are already undermining stability and posing tricky tests for US resolve.

In the world at large, the Bush-Rumsfeld concept brought a potential reversal of alliances by tying the positioning of bases, and other military cooperation arrangements, purely to operational considerations under the new global strategy. US documents defined maximum freedom of action as a must, ${ }^{15}$ which meant moving away from states that might impose limitations on the use of bases for political, legal or environmental reasons. The reliability of basing partners was also judged by their stance on the Global War on Terrorism and it was not surprising, after 9/11, that Saudi Arabia quickly went out of favour. But Turkey, one of the strongest anti-terrorist nations, also saw the US military partnership cut back after it declined to help with troop transit for an invasion of Iraq that it strongly opposed. The USA moved closer to states that claimed to be fighting the same enemies and were less fussy about how they did it, like Nepal or Colombia, some Arab states of the Gulf, or indeed the Central Asians. ${ }^{16}$ In one extraordinary move, Washington decided to threaten the withdrawal of all military aid from any state, even a NATO ally, that refused to make an agreement exempting US personnel from any charges brought before the new International Criminal Court. ${ }^{17}$

Such actions became increasingly hard to reconcile with the stress placed by the second George W. Bush Administration on 'democracy' as a condition of security; and US policy was re-balanced to some extent - with more emphasis on traditional partners, institutions, and multilateral regional systems - even before the Presidential elections of 2009. The overall legacy of post-9/11 base changes, however, has remained as a significant burden for President Obama in his efforts to project a more cooperative and caring US image world-wide: and there is little or no scope for any of the basing and stationing relationships now destroyed to be simply re-created. ${ }^{18}$ Indeed, the main decision Obama has made so far is to pull back on one new basing plan, namely the proposed missile defence sites in North Central Europe, in favour of focusing deployments for the next decade in Romania and using off-the-shelf interceptors already in service with the US Navy. ${ }^{19}$ 


\section{STJÓRNSÝSLA}

\section{Evaluation and Critique: Three Key Issues}

The Bush Administration's new basing strategy was never free from controversy and protest even in the USA itself, where it reflected among other things the Pentagon's ascendancy against more conservative State Department views. Congress presented two separate critical reports, one from the Congressional Budget Office in May 2004 and another from an ad hoc Overseas Basing Commission that reported in May 2005. Both questioned how real the financial savings would be, given that new facilities would have to be found in the USA - perhaps at higher per capita cost - for any personnel not simply demobilized. The OBC team also saw the base-cutting programme as over-hasty, poorly coordinated with other current defence plans, and grounded in false assumptions about relations with allies. Rumsfeld and his supporters, however - who had actually tried to block the creation of the $\mathrm{OBC}$ - brushed all such criticisms aside and continued to maintain that their plans were 'deliberate, throughtful and flexible'. ${ }^{20}$

With the benefit of several more years' hindsight, the Congressional critics' views now seem remarkably prescient, and not least on the financial aspects. Even if base closures were far from the main cause of US military overspending from 2004 onwards, they boosted the scale of national budget and trade deficits that turned out to be a serious factor of vulnerability for the USA -with equally serious long-term strategic consequences - when the 2008 financial crisis hit. ${ }^{21}$ This financial dimension would be worthy of a whole study in itself. In this section, however, the pros and cons of the new basing strategy will be treated under three different and more generic headings. First, it will be asked whether the new force postures and doctrines that underpinned the strategy brought the results that were hoped for in technical and operational terms. Secondly, the political impact of regional and local base changes will be discussed. The third question is whether the overall geographical re-alignment made sense in terms of the actual threat pattern emerging for the USA in the $21^{\text {st }}$ century.

\subsection{Military-technical aspects}

Defense Secretary Rumsfeld's faith in the combination of small mobile forces, top technology and remote strikes for tackling overseas challenges was always a hypothesis rather than based on objective study, and it was never fully shared by the mainstream of US force commanders. Several published accounts of the Afghanistan and Iraq wars have now underlined the extent of military misgivings and uncertainty, and the appeals that were made at every stage for larger force numbers and more considered tactics. ${ }^{22}$ Looking back, neither side was completely right because the new-style deployments did achieve a remarkably rapid conquest of territory and an end to organized military opposition, above all in Iraq. Ultimately, however, the old clichés reasserted themselves: winning a battle is not winning a war, and no threat can be fully eliminated by military means alone. Sparse spearhead forces tasked for combat and only for combat could not hold down territory, disarm the defeated side and clear the space of weaponry, or control the rapidly proliferating 'insurgency' phase of local opposition that followed. ${ }^{23}$ Even less could they win hearts and minds, nurture local alliances, and guide reform and reconstruction in the crucial phase of post-conflict peace-building, where a sensitive 
interplay of military and civilian contributions is nowadays seen as essential. It was very revealing that first in Iraq and then in Afghanistan, the USA's best and brightest commanders had to force through new approaches that tried to do less - in terms of leaving more to local allies and other international actors, and buying over rather than defeating some enemies - but at the same time called for substantially more US troops in the form of 'surges'. ${ }^{24}$

US defence analysts were not slow to draw the general lessons. The way that Rumsfeld's approach had underestimated and misused manpower became a hot theme of debate, ${ }^{25}$ and as the situation soured further in Iraq his critics within the defence establishment grew more vociferous. Already in the Quadrennial Defense Review of 2006, ${ }^{26}$ more serious attention was devoted to the challenges of counter-insurgency operations and the case was made for a significant increase in US active troop numbers overall, with special priority for creating more 'special operations' units, and better back-up by reserves. (The existing US National Guard had been badly overstrained since 2003, with members sometimes forced to serve abroad for over a year, and ranks thinned out at home to an extent that proved problematic in tackling Hurricane Katrina.) The same line of thought was reflected in the US forces' first counter-insurgency manual published in December 2006.

True, the shift in US thinking towards reliance on human skills more than hi-tech hardware, and on accepting the long-term effort required for success in any intervention with transformative goals, did not in itself make the Rumsfeldian basing concept redundant. Right up to the present, US strategy has continued to stress the need for rapidly deployable capacities under full national control, which implies that any lasting increase in US troop numbers will swell home-based forces rather than non-combatrelated stationing overseas. Two more general lessons learned do, however, tend to call in question the radical scale of the 2003-4 base re-positioning plans. First, US planners have had to re-learn the importance of local knowledge, including cultural sensitivity, and of selecting the right partners and allies both within the theatre of combat and among members of an intervening coalition. This suggests that long-term bases allowing US personnel to experience different conditions, and bases designed to underpin long-term cooperation - also with western allies - are by no means a waste of effort or out-of-date. This same issue is explored from a more political viewpoint in the next sub-section. Secondly, while it may be too early to speak yet of a second 'Vietnam syndrome', bitter experience in Iraq and Afghanistan has greatly reduced the official as well as popular US appetite for any similar venture in the near to medium future. ${ }^{27}$ It follows that shifting the basing pattern to one designed primarily to allow through-put and rear support for locally deployed combat forces may no longer fit the USA's own best strategic plans and needs: and this theme is taken further in 3.3 below.

\subsection{Political Aspects}

Secretary Rumsfeld's insistence that bases should be positioned according to purely operational logic, and should be insulated as far as possible from local politics and opinion, reflected his whole vision of foreign relationships. Frustrated by what he saw as insti- 


\section{STJÓRNSÝSLA}

tutional micro-management in the 1999 NATO campaign against Serbia, he famously declared that 'the mission must determine the coalition', not vice versa. In other words the USA should not let itself be tied down by formal institutions and former friendships, but should choose whom to work with - if anyone - ad hoc for each occasion and could set the rules to suit itself. Anyone who failed to come on board with positive contributions could expect no hearing for their opinions, and little claim to US help with their own concerns. The best partners would be the most compliant ones, and Washington would be looking for them in some rather strange new places.

The Congressional OBC report of $2005^{28}$ already exposed the flaw in this position by pointing out that the USA's pre-9/11 alliances and basing choices had been designed to serve real American interests, not to do a favour to the countries concerned. Throwing them over would only make sense if all previous threats and uncertainties (eg. from Russia) had disappeared overnight, if the old friends themselves had turned enemies, or if their help was no longer needed - none of which, clearly, was the case. Despite European opposition to the war in Iraq, a majority of EU members backed that US operation at least politically, and France and Germany were in the Afghanistan 'coalition' from the start. The support of developed economies, including Japan and South Korea, was also vital for the non-military measures - political, economic and technical - that the USA was seeking to apply worldwide in the fight against terrorism. It was asking a great deal of such states, many of which had populations that were very uneasy about the whole line of Bush's strategy, to come running to cooperate when Washington needed them while at the same time hearing that they were irrelevant, unwanted and even unwelcome for dealing with the toughest new tasks.

It was an even more unsustainable policy - at least beyond the short term - for the USA to demand active and costly help against a terrorist danger that only a minority of its allies felt directly threatened by themselves, while at the same time drawing down sharply on the protection it had been giving them for their own worst fears. The consequences were seen as early as 2004 when countries like Spain, followed by Hungary, started withdrawing their troops from Iraq. ${ }^{29}$ The political ineptness of the new proposed bases was meanwhile well illustrated by events in Poland. Although the US planners insisted their proposed missile defence base there was aimed at Iran, the Poles knew perfectly well that Russia would never believe this and insisted on more defensive elements for themselves being included - which of course merely confirmed Russian suspicions. It is also worth noting that Polish public opinion was hostile, on balance, to hosting the base at all. The public opinion factor became the largest single embarrassment in the Japanese case, where the US effort to find new sites merely led to more open resistance from local populations, and where opposition focused also on the share of the costs that Japan itself was pressured to pay.

The fact is that bases throughout history have had many functions beyond the purely operational; that they will always have local and regional political fall-out, positive or negative; and that trying to link them with new non-territorial threat pictures and strategies will not prevent most of the world's nations and populations from reading their significance first and foremost in geo-political terms. A well-placed base can strengthen 
the sending and receiving country's relationship almost more through its symbolism of engagement and shared risk, and by the professional and personal bonds it creates over time between stationed forces and locals, than it does by its military-technical or operational impact. A base that oppresses and alienates local communities can erode a would-be alliance to the point where many other aspects of cooperation are thrown in doubt, and the locals may even start thinking about offering facilities to the opposite power. Equally, a base set up in an undemocratic and unstable country that accepts it for money or cynical convenience is hardly an asset that can be depended on for the longer term.

In sum, Rumsfeld's supposed tough realism in sweeping such political and psychological considerations aside was not realistic at all: and Congress was right to question whether, even on the most hard-headed and unsentimental view, it was serving the USA's own best interests. The final balance of benefit and damage can still not be drawn, but both in Europe and the Far East it will have included encouraging at least some states to turn to other protectors, and driving regional states generally to seek more self-sufficient solutions for their long-term security. ${ }^{30}$ True, the success of any such efforts also reduces the USA's overall strategic burden, which is what some in Washington sought at the time and may regard as even more necessary today. But as the USA cuts back its military engagement it must by definition become more dependent on other 'softer' factors of power for influencing and controlling both friends and enemies. Washington's political capital has been weakened enough by the main excesses of its post-9/11 strategy, and its role in the 2008 economic collapse, to let it be indifferent to added damage from inept handling of the basing issue.

What lessons can be learned, in this political dimension? It has already been suggested that US bases and forces, once removed from traditional locations - whether rightly or wrongly - are very unlikely to come back. The costs of re-opening are disproportionate, and a reinstated base can also be far more strategically provocative than a retained one. It would thus be unrealistic to hope that the lessons just outlined would be reflected in a renewed and improved US basing programme, handled in a politically optimal way. They may, however, inspire a more politically astute and responsive US approach to key allies in other contexts, both bilaterally and in institutional contexts: and this is arguably just what emerged in the first National Security Strategy produced by the new Administration of President Barack Obama in May 2010. ${ }^{31}$ Already in the Introduction to this document, the President lists the USA's strategic strengths as 'sturdy alliances, an unmatched military...' - in that order. Later, the text states that 'Alliances are force multipliers' and must be constantly cultivated. The USA 'will continue to maintain the capacity to defend our allies against old and new threats'. A more specific rationale for maintaining those traditional bases that have been spared so far is conveyed in further statements about enhancing 'the resilience of the U.S. forward posture', and strengthening 'our regional deterrence position' (although this last idea is linked with the still-controversial missile defence concept). In regard to Asia the Security Strategy speaks of the need to 'ensure a sustainable foundation for U.S. forces' in Japan and South Korea. 


\section{STJÓRNSÝSLA}

The Obama Administration has proved true to this new vision, notably, in the context of preparing NATO's new collective Strategic Concept, published at the Lisbon Summit on 19 November $2010 .^{32}$ One of that document's main themes is the need to keep the Alliance's basic collective defence guarantees viable and credible, by renewed attention to the security of Europe, and by combining defensive strength with active improvement of relations with Russia very much in the style of the Alliance's traditional, pre-9/11 posture. Measures envisaged to reassure European Allies include contingency planning for defence of the Baltic space and the promise of exercises with 'real defence' rather than anti-terrorist scenarios. As for NATO's collective command structure, further slimming-down is envisaged with a manpower saving of $35 \%$; but a significant new accent has been introduced with the provision that the remaining HQs will be more closely related to national HQs and 'will also ensure a regional focus'. ${ }^{33}$ The devil of these plans will of course lie in the detail, and tough challenges await NATO planners as they embark on designing a detailed new force posture (conventional and nuclear) in which the US troop presence must be explicitly addressed. The fundamental ambivalence caused by NATO's decision not to station foreign troops on new allies' territory will not go away, and the amount of reliance now being placed on a collective allied missile defence system may be risky if (politically and/or technically) the venture fails. However, there is ample evidence here that the USA has reconsidered and significantly modified the new strategic direction that George W. Bush and Donald Rumsfeld adopted barely a decade ago.

\subsection{Force Posture and Global Threat}

If the US military policy of the early 2000 s could be criticized for its methods (3.1) above), many would also question today whether its targets and priorities were rightly defined. The Bush Administration's second National Security Strategy, published in March 2006, ${ }^{34}$ already gave more prominence to global threats and risks unconnected with terrorism or with the 'Arc of Crisis', such as pandemics and natural disasters. It also accepted the importance of working with formal institutions and within lasting multilateral partnerships, to protect the USA's own best interests. By the time the new Administration of President Barack Obama published its own National Security Strategy in May 2010, ${ }^{35}$ revisionism had gone so far that the President's Introduction made the striking statement - echoing a passage in the EU's Security Strategy of $2003^{36}$ that 'what takes place within our borders will determine our strength and influence beyond them'. Most obviously underpinning this thought is the experience of the 2008 economic and financial crash, but Obama also brings factors such as education, innovation, image and influence (all components of 'soft power') into the picture. Externally, his Strategy calls for the widest possible cooperation against threats such as cyber-sttacks, disease, climate change, weak-state conflict and criminality as well as terrorism; and for the promotion of human rights and international law as well as democracy. It also discusses in detail the requirements for stability and progress in different regions of the world, and the principles for US engagement with the rising powers of China and India as well as Russia. Iraq, Afghanistan and Al-Qa'eda are still there in the 
picture but they have moved very far from the all-dominating imperative they represented in the 2002 strategy document.

It has already been suggested that current and future US thinking about bases may have to shift back from assumptions about frequent, large and remote combat missions to place them within a longer-term strategy that pays more attention to geo-politics, alliances, and local perceptions generally. If the vision of the Obama Security Strategy is taken as a starting point, not only is the rationale for a long-term US basing effort in Europe and East Asia quite clear, but the question arises whether new locations might become necessary to maintain deterrence and stability in the face of potentially expansionist rising powers. It would be unwise, however, to guess too soon at the answer. Obama's Strategy also hints strongly that the USA would welcome friendly regions becoming stronger in their own defence and security, and that Washington would rather stabilize relations with other large powers through positive cooperation and shared responsibility than by renewed Cold War-style confrontations. Both the present mood of risk aversion and the economic factors, including especially US economic interdependence with China, point in the same direction. Further, if more bases were envisaged to support the new strategy, current trends suggest that the preference would be for naval or air facilities and missile defence installations rather than large ground-force concentrations - not least because of hopes that the former will often be less confrontational. ${ }^{37}$ In sum, even if strategic policy has in some senses gone round in a circle since 2001, trends in military-technical development and the shift in world power balances have been more linear, which essentially rules out the option of full reversion to basing philosophies from the Cold War or even the 1990s.

\section{Territory and Power in the $21^{\text {st }}$ Century}

The previous section has been discussing the merits of strategy from a US or a more general Western viewpoint: but how does the rest of the world think about bases? Russia, as has been noted, has not moved far from a Cold-War (or older historical) conception, where bases communicate the extension of power beyond the homeland and serve to hold down neighbouring territories as much as to protect them. On the other side, India and China have yet to evolve an extended basing strategy, partly because they are at an early stage (at least militarily) in their transition from regional to potentially global powers, and partly because neither has an alliance with friendly neighbours who would allow bases on their territory. ${ }^{38}$ Neither, moreover, has in modern times owned a far-flung empire that would have both required and allowed the kind of remote colonial basing still practised - if on a small scale - by France and Britain. ${ }^{39}$ It is certainly possible that they will begin to develop an interest in bases as their naval forces and ambitions grow and as they see need, both to defend direct national interests such as trade routes, and to compete in deterrent postures with each other and the USA. It is, however, also conceivable that they will find newer solutions of their own, influenced inter alia by a Rumsfeld-like reasoning that mobile capabilities and long-range strike 


\section{STJÓRNSÝSLA}

weapons under their own control are ultimately more flexible than capacities tied down to someone else's land.

However, the role that territory plays in the construction of empires and the dynamics of global power-play is far from limited to the narrow question of bases. One tenet of classical geopolitical analysis was that empires grow in two main ways, from a land-based core and from a maritime periphery. ${ }^{40}$ In the former model, of which Russia is a good example, there is a constant push to control more land on the fringes, at least politically and economically, to suppress unruly neighbours and deepen the strategic cover for the heartland. It does not require a great stretch of the imagination to see the EU and NATO today following such a pattern in their own stage-by-stage territorial expansion to the East and South-east, however much they may dislike and reject the imperial analogy. ${ }^{41}$ Sea-borne powers can potentially expand in all directions by sea (and today, by air) and spread their influence over more remote territories, chosen for economic and strategic value rather than geographical coherence: but they too need a minimal control of key points for trading, fuelling, servicing, listening-posts and the like.

Another way to see the Bush/Rumsfeld experiment of the early 2000s is that it tried to break away from both these models, in order to focus defence more tightly on the actual homeland - threatened as it was more directly than ever before by non-state enemies - combined with long-range capabilities that used only minimal, and increasingly moveable, physical jumping-off points abroad. Under this approach, taking responsibility for extra territory overseas - directly or through deep partnership with allies was not only unnecessary but an unwanted burden and constraint. Hyper-modern as it may have seemed at the time, this general vision now looks out of key with the way the majority of the world is actually building its future.

As the $21^{\text {st }}$ century progresses, there is every reason to believe that land as such will become a commodity under greater pressure and in greater demand, for several reasons. Populations will expand in the regions with least margin to produce extra food for themselves, and the shortage of cultivable land will be aggravated by the impact of climate change. Water shortages will similarly focus attention on the geo-politics of drainage systems - on how they are controlled and shared - while growing pressure to maximize harvests from the sea will make access to fisheries management a more touchy issue than ever. The new sources of energy that nations are seeking to develop for safety and autonomy all (except nuclear) involve exploiting physical territory in new ways, from solar, wind and tidal energy to the new rage for developing oil and gas shales. Potential under-sea resources have also captured attention and led to competitive territorial claims in the Arctic zone. ${ }^{42}$ The world's emerging powers and those with money to invest have reacted logically enough by seeking new ways to earmark valuable resources outside their own territory: by purchasing land in Africa and South America to grow crops for themselves, as China, India and some Arab states have done; ${ }^{43}$ by buying up oil production from some smaller producers outside the West's clientele, as China has done ${ }^{44}$ and by mimicking the West's outsourcing vogue and planting new large manufacturing sites of their own in countries that have raw materials, growing supplies of cheap labour and maybe less strict environmental codes. Properly considered, the whole notion of 
carbon permit trading involves manipulating what happens on others' territory to seek the best balance of economic and ecological interests, while 'green' millionaires have sought to protect what they see as the highest cause by simply buying up remote natural areas to preserve them.

It would be crude and hasty to sum up these various trends as a new kind of imperialism. They may just as well be seen as a physical manifestation of what globalization means: just as people may move, migrate and settle from one end of the earth to another, new patterns of land ownership and usage can develop that reflect entirely new interactions of new partners and new ways of exercising - particularly, economic power. One should also resist a West-centric reflex of branding such new relationships as wrong and dangerous, at least when other powers pursue them. More important is whether they respect sovereignty and the internal and international rule of law; and in fact, an interesting debate has started on norms to manage the foreign purchase of food-producing land. ${ }^{45}$

What does seem clear, overall, is that access to and control over non-native territories is going to remain an important and perhaps even a growing aim in the strategies of leading world powers, and will be one determinant of the balance of success and influence between them, well into the twenty-first century. Whether military bases as such will remain, or re-emerge as, one of the important tools for such purposes is a question best left open at the moment. What does seem clear, however, is that it will become harder rather than easier to gain access to other people's land for both military and nonmilitary purposes without some degree of consent; and that durable consent will imply both mutual benefits and some degree of common purpose. Neither the existing nor the emerging great powers have had happy experiences lately with building empires through coercion and one-sided exploitation; and the "Arab Spring" of 2011 could turn out to be yet one more development driving this lesson home.

Ironically enough, the first years after 2001, when writers were debating what kind of 'empire' the newly combative USA was going to be, ${ }^{46}$ was precisely the time when Washington down-played the value of lasting geographical bases abroad and of lasting alliances with the partners who controlled them. The current US Administration has achieved a rapid re-think on this last point, at least. It remains to be seen whether the USA, and its partners in a post-imperial Europe, have both the imagination and the resources to keep pace with the changing significance and shifting forms of territorial outreach in a globalized and increasingly multi-polar 21st-century world. 


\section{Endnotes}

1 Force numbers quoted in different contexts tend to vary slightly, partly because the actual numbers fluctuate all the time. The facts and figures used in this section are drawn primarily from Lachowski (2007).

2 The UK, the next largest basing power in Germany, made parallel reductions while Canada withdrew all its troops from Europe by 1993.

3 The National Security Strategy of the United States of America published on 17 Sep. 2002; see White House (2002).

4 Text and related sources available on 'The Defense Strategy Review Page' at http://www.comw.org/qdr/01qdr.html

5 See U.S. Department of defense (2001b).Text of draft legislation and official fact-sheet available at http://www.defense.gov/advisories/advisory.aspx?advisoryid=721.

6 An unclassified version of this document was released to Congress on 17 September 2004, see US Department of Defense (2004).

7 In 2002 NATO moved further away from a regional concept of base coverage by giving all responsibility for operations to SACEUR's headquarters in Europe and all planning and innovation work to SACLANT at Norfolk, Virginia, while collective bases around the NATO periphery were further cut back.

8 For further analysis see Bailes (2005).

9 Russia's own basing policy is analysed in Lachowski (2007). To support its protests on the US missile defence basing plans, Russia could point out that NATO had explicitly promised at the time of enlargement not to place foreign forces or nuclear objects on any new member's territory. US lawyers found counter-arguments, but opinion within NATO remained uneasy and unclear on the matter and there was also considerable popular opposition within Poland and the Czech Republic.

10 See Bailes (2007). Other missile defence-related installations further west, in the UK and Greenland, are of less concern to Russia but have not gone without local protest.

11 In fact most Western facilities in the region, including French and German ones, are still operational and the Astana doctrine was not maintained by subsequent SCO Summits: see Bailes, Dunay, Guang and Troitskiy (2007). During 2010 in a context of NATO-Russia rapprochement, Russia tried a new tack by offering to let NATO use transit and support bases on its own territory.

12 The authoritative reports on this issue were produced by Dick Marty for the Council of Europe Parliamentary Assembly: see e.g. 'Secret detention and illegal transfer of detainees involving Council of Europe members: second report', COE Assembly document 11302rev of 11 June 2007.

13 Chanlett-Avery et al (2011).

14 Eyfells (2010).

15 Lachowski (2007).

16 For several years after the 2003 occupation of Iraq it was also assumed that the US would also seek permanent bases there to replace the former role of Saudi Arabia, keep Iran in check and keep the future Iraqi regime in line. After regaining full sovereignty, however, the Iraqi government made clear it would not countenance this - although a huge new US Embassy complex will remain.

17 Romania at first succumbed to Washington's demands, but EU member states then formed a common front to defend the ICC against US opposition and were able to hold the applicant countries with them.

18 This judgement takes account of the national reactions among both US politicans and the public against overseas adventures like those in Iraq and Afghanistan, and also of financial factors, given the impact of the 2008 economic crash and overall cuts now being planned in US military spending. The case is further argued in sections 3ii) and 3iii) below.

19 Defense News (2010).

20 Lachowski (2007), pp. 16-19.

21 Between 2001 and 2006 the USA's national defence spending rose from US\$304.9 to 535.9 billion and the cost of the global war on terrorism from US\$ 14 to 432 billion (of which US\$ 381bn. on Iraq and Afghanistan). US national indebtedness rose by US\$2.84 trillion and the national budget went from a US $\$ 128$ billion surplus to a US\$ 423 bn. deficit. All figures at constant (2007) prices, from Stålenheim et al (2007), pp 267-297.

22 Recent books focusing on the military debate include Hicks (2010).

23 It is notorious that the US commanders failed to realize the importance of collecting weapons after the Iraqi defeat, and that the occupying powers' provisional administration made a huge misjudgement by summarily disbanding the Iraqi army. Rumsfeld's team were curiously blind even to lessons that the USA itself had learned in the recent Balkan wars.

24 Hicks (2010). 
25 See for example Kagan (2006).

26 Department of Defense, Quadrennial Defense Review report, Washington, 6 Feb. 2006, text at http:/ / www.defenselink.mil/qdr.

27 One pointer in this direction could be the USA's rejection of a front-line role in NATO operations against Colonel Gaddafi's regime in Libya in Spring 2011.

28 Text and covering letter at www.fas.org/irp/agency/dod/obc.pdf.

29 All European contingents, including the British, had withdrawn by the end of 2009.

30 In the mid-2000s, European experiences with and splits over US policy clearly strengthened the shift of attention to the EU as an alternative setting for military cooperation, leading to several concrete steps to strengthen the EU's military crisis management policy ('European Security and Defence Policy') and the creation of an EU agency for armaments ('European Defence Agency'). By 2010-2011, however, the dynamics of ESDP were fading and the EU's Lisbon Treaty - entering into force December 2010 - made no real breakthrough to a purely European collective defence. For more on ESDP and EU-NATO relations see Bailes and MesservyWhiting (2011).

31 White House (2010).

32 North Atlantic Treaty Organization (2010a).

33 North Atlantic Treaty Organization (2010b), paragraph 49.

34 White House (2006).

35 White House (2010).

36 The European strategy document had recognized that alienation as a root cause of terrorism 'is also part of our own society'. See European Union (2003).

37 For example, the USA is thought to be interested in using naval facilities at Cam Ranh Bay in Vietnam, which might simultaneously be opened to Russian (but not Chinese) vessels.

38 This is not to say that there has not been extensive speculation and debate, focusing notably on India's involvement with an air base near Dushanbe in Tajikistan and rumours of a Chinese basing plan in Pakistan. Official defence policy in both states is to disclaim any strategic basing plans, while tolerating or even encouraging expert debate about the pros and cons.

39 For instance, France still uses a base in Djibuti and the UK has a garrison in the Falklands.

40 This concept is especially associated with Halford Mackinder, see Kearns (2009).

41 Alyson J.K. Bailes, 'The EU as Empire ('Good' or 'Evil')?' in 'Through European Eyes', Institute of International Affairs, University of Iceland, 2009 (text at

42 The importance of the Arctic theatre was recognized in the USA's Arctic Strategy adopted on 9 January 2009 (White House (2009)), which has led to some speculation over whether Washington might seek new bases to pursue its military and economic interests there. No such plans have yet been mooted, however, and it is worth noting that Washington's first focus must be on territorial protection for Alaska - i.e., in the Pacific zone. In the North Atlantic zone the US has concentrated recent development on the base at Thule in Northern Greenland, and this may or may not still prove adequate to meet the military desiderata set out in the strategy which refers to '... such matters as missile defense and early warning; deployment of sea and air systems for strategic sealift, strategic deterrence, maritime presence, and maritime security operations; and ensuring freedom of navigation and overflight.'

43 The Economist (2009).

44 China only started to import oil in 1993 but by 2009 was importing over half of its total consumption. Its choice of suppliers has at times created tension with both the USA and Russia, as explained in Forney (2004);but lately China's state oil company has also bought a share in the USA's own oil shale development.

45 See for instance Roy Laishley, 'Is Africa's land up for grabs?' in Africa Renewal Online, October 2009, at http://www.un.org/ecosocdev/geninfo/afrec/vol23no3/233-land.html.

46 An example is Andrew J. Bacevich, 'American Empire: The realities and consequences of U.S. Diplomacy', Harvard University Press 2002. A short but telling criticism of such discourse is the op-ed of 3 February 2003 by Paul Schroeder at the History News Network, http://hnn.us/articles/1237.html. 


\section{References}

Bacevich, A.J. (2002). "American Empire: The realities and consequences of U.S. Diplomacy", Harvard University Press 2002

Bailes, A.J.K. (2005). "How Collective is our Defence?”, Sicherbeit und Frieden (Institut für Friedensforschung und Sicherheit, Hamburg), vol. 23, no. 2, 2005

Bailes, A.J.K. (2007). "Putins Poker" (in German) in Internationale Politik (Deutsche Gesellschaft für Auswärtige Politik, Berlin), June 2007

Bailes, A.J.K., Dunay, P., Guang, P. and Troitskiy, N., “The Shanghai Cooperation Organization”, SCO Policy Paper No. 17 of May 2007, text at http://books.sipri.org/product_info?c_product_id=338.

Bailes, A.J.K. (2009). “The EU as Empire ('Good' or 'Evil')?”' in Through European Eyes, Institute of International Affairs, University of Iceland, 2009

Bailes, A.J.K. and Messervy-Whiting, G. (2011). "Death of an Institution: The end for Western European Union, a future for European defence?”, Egmont Institute Occasional Paper Nr 46 (Brussels), accessed June 2011 at http://www.egmontinstitute.be/paperegm/sum/ep46.html.

Chanlett-Avery, E., Cooper, W.H. and Manyin, M.E (2011). “Japan-U.S. Relations: Issues for Congress", Congressional Research Service January 13 2011, accessed March 2011 at http://www.fas.org/sgp/crs/row/RL33436.pdf.

Council of Europe Parliamentary Assembly (2007). "Secret detention and illegal transfer of detainees involving Council of Europe members: second report", COE Assembly document 11302rev of 11 June 2007.

Defense News (online) (2010). "Analysts Laud Revised US Plan for Europe”, 22 March 2010, accessed January 2011 at http://www.defensenews.com/story.php?i=4547992.

The Economist (2009). "Outsourcing's third wave", 21 May 2009, accessed January 2011at http://www.economist.com/node/13692889.

European Union (2003). "A Secure Europe in a Better World", European Security Strategy, accessed January 2011 at www.consilium.europa.eu/uedocs/cmsUpload/78367.pdf .

Eyfells, E. (2010). “Japan's Security Dilemma: Altering Article 9” (MA thesis, University of Iceland)

Forney, M. (2004). "China's Grab for Oil", Time, 18 October 2004, accessed January 2011 at http://www.time.com/time/magazine/article/0,9171,725174,00.html

Hicks, T.E. (2010). “The Gamble: General David Petraeus and the American Military Adventurism in Iraq, 2006-2008”, London: Penguin Books.

Kagan, F.W. (2006). “The U.S. military's manpower crisis”, Foreign Affairs vol 85 no. 4 of July/August 2006, pp 97-110.

Kearns, J. (2009). "Geopolitics and Empire: The legacy of Halford Mackinder", Oxford: Oxford University Press.

Lachowski, Z. (2007). 'Foreign Military Basing in Eurasia', SIPRI Policy Paper No 18 of June 2007, text at http://books.sipri.org/product_info?c_product_id=339.

Laishley, R. (2009). "Is Africa's land up for grabs?”, Africa Renewal Online, October 2009, accessed January 2011 at http://www.un.org/ecosocdev/geninfo/afrec/vol23no3/233-land.html.

North Atlantic Treaty Organization'(2010a). 'Active Engagement, Modern Defence', New NATO Strategic Concept, accessed January 2011 at http://www.nato.int/cps/en/natolive/news_68172.htm.

North Atlantic Treaty Organization (2010b). Declaration of the NATO Lisbon Summit, 19-20 November 2010, accessed January 2011 at http://www.nato.int/cps/en/SID-122B8F1E- 
03EB54BA/natolive/official texts $68828 . \mathrm{htm}$ ? mode=pressrelease.

Schroeder, P. (2002). "Is the U.S. an Empire?”, History News Network 3 March 2002, accessed March 2011 at http://hnn.us/articles/1237.html.

Stålenheim, P., Perdomo, C. and Sköns, E. (2007). "Military Expenditure" in SIPRI Yearbook 2007: Armaments, Disarmament and International Security, OUP: London.

U.S. Congress (2005). Overseas Basing Commission report (with covering letter), www.fas.org/irp/agency/dod/obc.pdf.

U.S. Department of Defense (2001a). Quadrennial Defense Review 2001, text at the Defense Strategy Review Page, http://www.comw.org/qdr/01qdr.html

U.S. Department of Defense (2001b). "Efficient Facilities Initiative", draft law and fact-sheet, http://www.defense.gov/advisories/advisory.aspx?advisoryid=721.

U.S. Department of Defense (2004). 'Strengthening U.S global defense posture', http://www.defensecommunities.org/resourcecenter/Global Posture.pdf.

U.S. Department of Defense (2006). Quadrennial Defense Review report, Washington, 6 Feb. 2006, text at http://www.defenselink.mil/qdr.

White House (2002). The National Security Strategy of the United States, accessed January 2011 at https://digitalndulibrary.ndu.edu/cdm4/document.php?CISOROOT=/strategy\&CISOPTR=523 $1 \& \mathrm{REC}=2$.

White House (2006). The National Security Strategy of the United States, accessed January 2011 at http://georgewbush-whitehouse.archives.gov/nsc/nss/2006/.

White House (2009), Arctic Strategy of the United States, accessed January 2010 at http://geopoliticsnorth.org $/$ index.php?option $=$ com_content\&view $=$ article\&id $=84 \&$ Itemid $=69 \&$ limitstart $=3$ ),

White House (2010). The National Security Strategy of the United States, accessed January 2011 at http://www.whitehouse.gov/issues/defense. 
